\title{
A SPATIALLY ALLOCATED EMISSIONS INVENTORY FOR CYPRUS
}

\author{
G. TSILINGIRIDIS ${ }^{1, *}$ \\ C. SIDIROPOULOS ${ }^{1}$ \\ A. PENTALIOTIS ${ }^{1}$ \\ C. EVRIPIDOU ${ }^{1}$ \\ C. PAPASTAVROS ${ }^{2}$ \\ T. MESIMERIS ${ }^{2}$ \\ M. PAPASTAVROU ${ }^{2}$
}

Received: 07/12/09

Accepted: 11/02/10

\author{
${ }^{1}$ Department of Mechanical Engineering, \\ Aristotle University of Thessaloniki, Greece \\ ${ }^{2}$ ECOGNOSIA, 46 Mekodonitissis Avenue, \\ P.C. 240 05, Nicosia, Cyprus
}

\begin{abstract}
In this paper, a detailed spatial allocated emissions inventory for Cyprus is presented. Topdown and bottom-up methodologies are implemented and emissions are estimated from all anthropogenic sources for the reference year 2002 with the aid of state-of-the-art algorithms. Emission factors representative for the situation in Cyprus, in the case of major industrial units, and default emission factors for the rest emission sources are adopted. Main results indicate that power generation and road transport are the major contributors to total emissions. Power generation share was $36 \%$ in total $\mathrm{CO}_{2}, 62 \%$ in total $\mathrm{SO}_{2}, 20 \%$ in total $\mathrm{NO}_{\mathrm{x}}$ and $55 \%$ in total $\mathrm{N}_{2} \mathrm{O}$ emissions, while the share of road transport was $29 \%$ in $\mathrm{CO}_{2}, 22 \%$ in $\mathrm{SO}_{2}, 35 \%$ in $\mathrm{NO}_{x}$ and $6 \%$ in $\mathrm{N}_{2} \mathrm{O}$ emissions. Furthermore, comparisons to other existing emission inventories for Cyprus and official national emission data are presented and differences are partially explained.

A GIS-based approach is applied to generate, organize and spatially allocate emissions data in a $5 \times 5 \mathrm{~km}^{2}$ grid. GIS-aided spatial overlay techniques are used and maps of spatial allocation factors and gridded emissions data are produced and presented, showing that highest emission densities appear in cells, which include large industrial plants and/or cover urban areas.
\end{abstract}

KEYWORDS: Air pollutants, air quality, emission allocation, gridded data, GIS.

\section{INTRODUCTION}

Air pollution extends from local (urban pollution) to regional (dispersion, deposition and chemical transformation of the pollutants, acid rain, photochemical reactions) and global level (greenhouse effect and depletion of the stratospheric ozone layer). Air pollution modelling is a powerful tool capable of assisting policy makers in developing abatement strategies to reduce pollutant emissions.

One of the most crucial data sets needed to initiate chemical and photochemical reaction mechanisms included in an air quality model is the emissions inventory. An emission inventory identifies sources of air pollutants in an area and quantifies emissions from specific sources (Baldasano, 1998). Nowadays, emission inventories are under constant development and improvement worldwide. Photochemical air quality models use meteorological, topographic and emission inventory data to simulate the physical and chemical processes that influence primary or secondary pollutants, i.e. the ozone formation in an airshed. Gridbased air quality models portray the modelling region as a 3-dimensional grid matrix and pollutant concentrations are predicted for each individual grid cell in the modelling domain. To accurately represent the geographic distribution of emissions throughout a gridded modelling 
domain, it is necessary to develop an emission inventory that reports emissions corresponding to each grid cell of the domain (Taghavi et al., 2005). Therefore, detailed emission inventories are required as input to air quality models and must include the emission estimates reported at a grid-cell level. Modelling grids may extend over small or larger domains and may include hundreds or thousands of grid cells depending on grid resolution.

According to recent findings, concentrations of several air pollutants in the cities of Cyprus regularly exceed the limits set by the new European Union regulations for air quality (DLI, 2009). However, work on emissions inventorying in Cyprus is rather limited, i.e. a first systematic approach of emissions inventory has been compiled for 2001 (Baumbach et al., 2007) and another for 2006 (Mellios and Samaras, 2009). In this paper an improved, spatially allocated emissions inventory for Cyprus is developed and presented. Activity statistics collected from various sources together with default and country-specific emission factor data sets have been used to estimate $\mathrm{CO}_{2}, \mathrm{SO}_{2}, \mathrm{NO}_{x}, \mathrm{NMVOC}, \mathrm{CH}_{4}, \mathrm{CO}$ and $\mathrm{N}_{2} \mathrm{O}$ emissions from all anthropogenic sources. For the emissions allocation, a $5 \times 5 \mathrm{~km}^{2}$ grid was created. Even though the modelling domain covers the whole of Cyprus, emissions were calculated only for the Greek Cypriot part due to the lack of access in data from the northern part of the country. Spatial overlay techniques are implemented in an integrated framework of a GIS and a database management system to provide examples of emission density maps over Cyprus. Apart from readily available emission data to be used as input data in grid-based air quality models, this paper also presents comparisons with emissions data from other inventories and official national emission data. Limitations of the inventories are discussed and suggestions are made for the improvement of inventories so as to provide more reliable emission data.

\section{METHODOLOGY}

The estimation of emissions is based on the EMEP/CORINAIR methodology of the European Environment Agency (EEA) (EMEP/CORINAIR, 2007). The Quantity (Q) of each air pollutant emitted depends on the Activity Level (AL) and the Emission Factor (EF), a factor which defines the linear relationship between $Q$ and $A L$ according to the general formula:

$$
\mathrm{Q}_{\mathrm{s}, \mathrm{i}, \mathrm{j}, \mathrm{k}}=10^{-6} \times \mathrm{EF}_{\mathrm{s}, \mathrm{i}, \mathrm{j}, \mathrm{k}} \times \mathrm{AL}_{\mathrm{s}, \mathrm{i}, \mathrm{j}}
$$

where

$\mathrm{s} \quad$ refers to the pollution source examined

i refers to the technology (industrial boiler, vehicle type, airplane type, solvent-related products, etc)

j refers to the activity (combustion of diesel, heavy fuel oil, vehicle km driven, airplanes landing and take off cycles operated, commodities production, etc)

$k \quad$ refers to the pollutant examined

$Q_{s, i, j, k}$ is the quantity of pollutant $k$, from source $s$, technology $i$ and activity $j$ (in $t y^{-1}$ )

$E F_{s, i, j, k}$ is the emission factor for pollutant $k$, for source $s$, technology $i$ and activity $j$ (in $\mathrm{g} \mathrm{GJ}^{-1}$ or in $\mathrm{g}$ veh $\mathrm{km}^{-1}$ or in $\mathrm{g} \mathrm{LTO}^{-1}$ or in $\mathrm{g} \mathrm{t}^{-1}$, etc)

$A L_{s, i, j}$ is the activity level of the emission source $s$, the technology $i$ and the activity $j$ (in $t \mathrm{yr}^{-1}$ or in $\mathrm{GJ}_{\mathrm{yr}} \mathrm{r}^{-1}$ or in veh $\mathrm{km} \mathrm{yr}^{-1}$ or in LTO $\mathrm{yr}^{-1}$, etc)

Activity level data for each emission source was acquired through an extensive data collection campaign mainly from statistical handbooks (primarily from the Statistical Service of the Republic of Cyprus as well as from other public services), scientific publications, research on the Internet, personal communication with experts working in industry, etc. Table 1 summarizes the emission source activities examined, the fundamental data for the emissions calculation as well as the origin of data. The emission factors used were derived from the Atmospheric Emissions Inventory Guidebook (EMEP/CORINAIR, 2007) and, where it was available, directly from measurements in factories (e.g. in the case of emission factors of Cypriot cement factories). 
Table 1. Activity data by emission source category and data sources (2002)

\begin{tabular}{|c|c|c|}
\hline Emission source activity & Activity data & Data source \\
\hline Power generation & $\begin{array}{l}\text { Units technical characteristics } \\
\text { Fuel consumption }\end{array}$ & $\begin{array}{l}\text { EAC }^{1} \\
\text { SSRC-Sales and hold-up } \\
\text { data of oil products }\end{array}$ \\
\hline Refinery & $\begin{array}{l}\text { Units technical characteristics } \\
\text { Fuel consumption } \\
\text { Oil balance }\end{array}$ & Cyprus Refinery \\
\hline Cement factories & $\begin{array}{l}\text { Cement production } \\
\text { Fuel consumption }\end{array}$ & $\begin{array}{l}\text { Cement factories in Vasiliko } \\
\& \text { Moni }\end{array}$ \\
\hline $\begin{array}{l}\text { Combustion in large point } \\
\text { sources }\end{array}$ & Fuel consumption & $\begin{array}{l}\text { SSRC }{ }^{2} \text {-Sales and hold-up } \\
\text { data of oil products }\end{array}$ \\
\hline $\begin{array}{l}\text { Combustion in small units } \\
\text { Space heating }\end{array}$ & $\begin{array}{l}\text { Fuel consumption } \\
\text { Fuel consumption }\end{array}$ & \\
\hline Production processes & Commodities production & SSRC-Industry statistics \\
\hline Petrol distribution & $\begin{array}{l}\text { Petrol consumption per activity } \\
\text { (storage, distribution, carriage) }\end{array}$ & $\begin{array}{l}\text { SSRC-Sales and hold-up } \\
\text { data of oil products }\end{array}$ \\
\hline Solvents use & $\begin{array}{l}\text { Import, export, production of } \\
\text { relevant chemical compounds } \\
\text { and products }\end{array}$ & $\begin{array}{l}\text { SSRC-Import and export } \\
\text { statistics }\end{array}$ \\
\hline Agriculture-Livestock & $\begin{array}{l}\text { Fertilizer utilization, } \\
\text { Number of animals }\end{array}$ & SSRC-Agricultural Statistics \\
\hline Road transport & $\begin{array}{l}\text { Vehicle distribution per age, } \\
\text { category, cc and fuel }\end{array}$ & SSRC-Transport Statistics \\
\hline Sea transport & Arrivals/departures of ships & $\mathrm{CPA}^{3}$ \\
\hline \multirow{2}{*}{$\begin{array}{l}\text { Air transport } \\
\text { Off road transport }\end{array}$} & \multirow{2}{*}{$\begin{array}{l}\text { LTO cycles of airplanes } \\
\text { Import, export of off-road } \\
\text { vehicle \& machinery }\end{array}$} & $\mathrm{DCA}^{4}$ \\
\hline & & Cyprus Customs \\
\hline
\end{tabular}

${ }^{1}$ EAC: Electricity Authority of Cyprus

${ }^{2}$ SSRC: Statistical Service of the Republic of Cyprus

${ }^{3} \mathrm{CPA}$ : Cyprus Port Authority

${ }^{4}$ DCA: Department of Civil Aviation

Emissions are typically classified in three types of sources according to their spatial characteristics:

- $\quad$ Stationary or point source emissions originate from large point sources at fixed locations (such as power plants and industrial facilities),

- $\quad$ Mobile or line sources (e.g. all on-road vehicles), and

- Area sources which are stationary and/or mobile sources that are transient and widespread (for example emissions related to solvent use or to off-road machinery operation).

A GIS-based approach was applied to generate, organize and display gridded emissions data. The geographic locations of large point sources, such as power plants and factories are known, providing a method to assign emissions from these sources directly to their specific locations. In contrast, line and area sources are usually smaller, transient and widely distributed throughout a region. Due to the fact that the exact locations of line and area sources are often unknown, the geographic distribution of these sources must be approximated using emissions surrogates. This surrogate data (e.g. road traffic counts, population density, housing statistics, etc.) is used as indicators of emissions activity because their spatial distributions are assumed to be representative of the geographic distribution of emissions sources.

In Figure 1 the spatial allocation of the major emission sources, e.g. urban and other built up areas, highways, industrial areas and large industrial plants, is presented. 

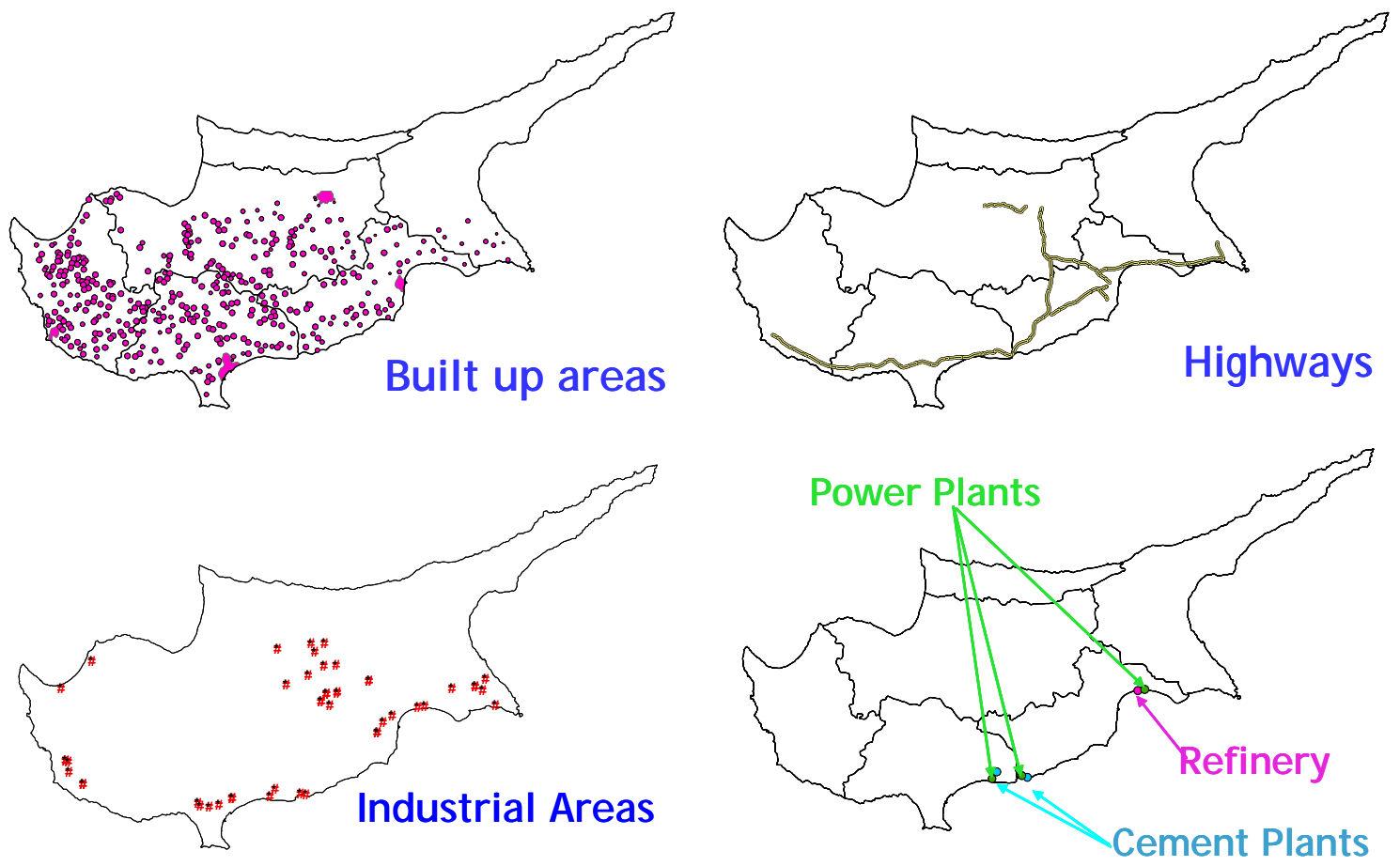

Figure 1. Spatial allocation of major emission sources

A thorough review was performed to identify sources of various spatial data sets appropriate for use in the development of emissions surrogates and spatial allocation factors in the case of Cyprus. The development of emissions surrogates was a labour-intensive process that involved acquiring, formatting, and processing spatial data sets in several different formats and from many different sources. Spatially resolved surrogate data associated with point, line, or polygon geographic features were obtained from local transportation and/or planning organizations, state agencies and commercially available data sources. The spatial data sets created were then imposed onto the defined modelling grid and the geographic features were disaggregated into the grid cells. This was made possible using GIS-aided spatial overlay techniques analyzed elsewhere in detail (Dai and Rocke, 2000; Sidiropoulos and Tsilingiridis, 2006). Finally, maps of spatial allocation factors and gridded emissions data were produced.

More details on data, estimation procedures, results and spatial allocation can be found elsewhere (Tsilingiridis and Fessas, 2008).

\section{RESULTS AND DISCUSSION}

In Table 2 the shares of each emission source category to total emissions are presented. Power generation and road transport are the major contributors to total emissions in Cyprus. Power generation share was $36 \%$ in total $\mathrm{CO}_{2}, 62 \%$ in total $\mathrm{SO}_{2}, 20 \%$ in total $\mathrm{NO}_{x}$ and $55 \%$ in total $\mathrm{N}_{2} \mathrm{O}$ emissions, while the share of road transport was $29 \%$ in total $\mathrm{CO}_{2}, 22 \%$ in total $\mathrm{SO}_{2}$, $35 \%$ in total $\mathrm{NO}_{x}, 48 \%$ in total NMVOC and $78 \%$ in total CO emissions.

In order to validate the inventory, emissions results from existing emissions inventories for Cyprus are presented as well. Table 3 summarizes the emission results from inventories compiled by the Ministry of Labour and Social Insurance of Cyprus, Department of Labour Inspection for the years 2001 and 2002 (DLI, 2009). Table 4 shows the first systematic approach of emissions inventory compiled for the year 2001 (Baumbach et al., 2007). Significant differences are observed between the three inventories for $\mathrm{CO}$ emissions (especially in the transport sector), while for $\mathrm{SO}_{2}$ emissions, a fuel-dependent pollutant, the deviations are non-significant. As far as $\mathrm{NO}_{x}$ emissions are concerned, the $D L /$ results are in good agreement with the results of the work conducted by Baumbach et al., but about half of the present work results. In the present work NMVOC emissions are about $30 \%$ higher than $D L I$ results, while total VOC emissions are higher than Baumbach et al. work by a factor of 3. 
Table 2. Air pollutant emissions by emissions source category in Cyprus

\begin{tabular}{|c|c|c|c|c|c|c|c|}
\hline $\begin{array}{l}\text { Emission Source } \\
\text { Category }\end{array}$ & $\mathrm{CO}_{2}$ & $\mathrm{SO}_{2}$ & $\mathrm{NO}_{\mathrm{x}}$ & NMVOC & $\mathrm{CH}_{4}$ & $\mathrm{CO}$ & $\mathrm{N}_{2} \mathrm{O}$ \\
\hline Power generation & $36.0 \%$ & $61.6 \%$ & $19.6 \%$ & $1.8 \%$ & $0.2 \%$ & $1.4 \%$ & $55.1 \%$ \\
\hline Refinery & $1.2 \%$ & $1.6 \%$ & $0.8 \%$ & $0.1 \%$ & $0.1 \%$ & $.5 \%$ & $0.5 \%$ \\
\hline Cement factories & $7.4 \%$ & $6.9 \%$ & $4.3 \%$ & $0.2 \%$ & $0.3 \%$ & $0.6 \%$ & $1.5 \%$ \\
\hline $\begin{array}{l}\text { Combustion in the } \\
\text { rest large point } \\
\text { sources }\end{array}$ & $7.6 \%$ & $0.3 \%$ & $0.4 \%$ & $0.0 \%$ & $0.0 \%$ & $0.2 \%$ & $0.0 \%$ \\
\hline $\begin{array}{l}\text { Combustion in small } \\
\text { units }\end{array}$ & $6.8 \%$ & $0.7 \%$ & $0.3 \%$ & $0.0 \%$ & $0.0 \%$ & $0.1 \%$ & $0.6 \%$ \\
\hline Space heating & $6.7 \%$ & $5.5 \%$ & $0.9 \%$ & $0.5 \%$ & $0.2 \%$ & $0.9 \%$ & $1.9 \%$ \\
\hline Production processes & & & & $12.7 \%$ & & & \\
\hline Petrol distribution & & & & $4.6 \%$ & & & \\
\hline Solvents use & & & & $12.5 \%$ & & & \\
\hline Agriculture-Livestock & & & $1.9 \%$ & & $96.0 \%$ & & $23.2 \%$ \\
\hline Road transport & $28.7 \%$ & $21.9 \%$ & $35.2 \%$ & $47.8 \%$ & $2.7 \%$ & $78.8 \%$ & $5.6 \%$ \\
\hline Sea transport & $0.2 \%$ & $0.1 \%$ & $1.0 \%$ & $0.1 \%$ & $0.0 \%$ & $0.1 \%$ & $0.0 \%$ \\
\hline Air transport & $0.2 \%$ & $0.1 \%$ & $1.0 \%$ & $0.9 \%$ & $0.1 \%$ & $1.0 \%$ & $0.1 \%$ \\
\hline Off road trar & $5.2 \%$ & $1.4 \%$ & $34.4 \%$ & $18.8 \%$ & $0.3 \%$ & $16.4 \%$ & $11.5 \%$ \\
\hline Total $\left[\mathrm{kt} \mathrm{yr}^{-1}\right]$ & 8277 & 50 & 41 & 21 & 15 & 55 & 3 \\
\hline
\end{tabular}

Table 3. National air pollutant emissions by emissions source category (DLI, 2009)

\begin{tabular}{|c|c|c|c|c|c|c|c|c|}
\hline \multirow{2}{*}{$\begin{array}{l}\text { Emission Source } \\
\text { Category }\end{array}$} & \multicolumn{2}{|c|}{$\mathrm{SO}_{2}$} & \multicolumn{2}{|c|}{$\mathrm{NO}_{\mathrm{x}}$} & \multicolumn{2}{|c|}{ NMVOC } & \multicolumn{2}{|c|}{$\mathrm{CO}$} \\
\hline & 2001 & 2002 & 2001 & 2002 & 2001 & 2002 & 2001 & 2002 \\
\hline Energy production & 29.83 & 30.2 & 5.64 & 6.49 & 1.78 & 2.06 & 0.45 & 0.52 \\
\hline Refinery & 0.98 & 1.1 & 0.20 & 0.17 & 0.73 & 0.68 & & \\
\hline $\begin{array}{l}\text { Manufacturing Industry \& } \\
\text { Construction }\end{array}$ & 4.77 & 5.7 & 0.48 & 0.53 & 0.05 & 0.06 & 0.81 & 0.98 \\
\hline Transportation & 7.29 & 10.08 & 10.05 & 10.08 & 9.39 & 9.09 & 84.36 & 80.93 \\
\hline Central Heating & 2.74 & 2.63 & 0.57 & 0.55 & 0.09 & 0.08 & 0.11 & 0.10 \\
\hline $\begin{array}{l}\text { Agriculture (pumps- } \\
\text { tractors) }\end{array}$ & 0.82 & 0.84 & 0.69 & 0.67 & 0.14 & 0.15 & 0.53 & 0.52 \\
\hline Oil storage & & & & & 0.25 & 0.24 & & \\
\hline Oil distribution & & & & & 0.52 & 0.53 & & \\
\hline Cement production & 3.38 & 3.34 & 3.78 & 3.73 & 0.01 & 0.01 & 0.48 & 0.47 \\
\hline Lime production & 0.04 & 0.04 & 0.01 & 0.01 & & & & \\
\hline Paints & & & & & 2.40 & 2.66 & & \\
\hline Dry cleaning & & & & & 0.20 & 0.20 & & \\
\hline Solvents (rest) & & & & & 0.28 & 0.23 & & \\
\hline Total emissions $\left[\mathrm{kt} \mathrm{yr}^{-1}\right]$ & 49.85 & 50.72 & 21.42 & 22.23 & 15.84 & 15.99 & 86.74 & 83.52 \\
\hline
\end{tabular}

Table 4. Air pollutant emissions in the Greek Cyprus Community area for the year 2001

(Baumbach et al., 2009)

\begin{tabular}{lrrrrr}
\hline $\begin{array}{l}\text { Emission Source } \\
\text { Category }\end{array}$ & $\mathbf{S O}_{2}$ & $\mathbf{N O}_{\mathbf{x}}$ & VOC & CO & PM \\
\hline Boilers & 39.93 & 11.75 & 0.52 & 0.22 & 1.66 \\
Dry cleaners & 0.33 & 0.03 & 0.21 & 0.01 & 0.01 \\
Hotels & 0.09 & 0.02 & 0.00 & 0.01 & 0.00 \\
Domestic Heating & 1.67 & 0.07 & 0.00 & 0.10 & 0.04 \\
Agriculture & 0.50 & 0.02 & 0.00 & 0.03 & 0.01 \\
Petrol stations & - & - & 0.74 & - & - \\
Aircrafts & 0.02 & 0.26 & 2.61 & 0.06 & 0.09 \\
Road Traffic & 7.08 & 13.26 & 8.27 & 39.55 & 0.67 \\
\hline Total emissions $\left[\mathrm{kt} \mathrm{yr}^{-1}\right]$ & 49.62 & 25.40 & 12.35 & 39.98 & 2.47 \\
\hline
\end{tabular}


In Table 5 the comparison of the emission sources' contribution of the present work (PW) to the inventory compiled for the year 2006 by the Laboratory of Applied Thermodynamics (LAT) of Aristotle University of Thessaloniki, Greece (Mellios and Samaras, 2009) is presented. LAT inventory, which is based on the EMEP/CORINAIR methodology, too, includes some additional emission categories, the most important being the "Waste management", but misses some others, the most important being the "Off road vehicles and machinery". Moreover, contribution of most categories in total emissions shows deviations, which in most cases are important and cannot be attributed to the four years difference in the reference time of the inventories. Finally, LAT inventory reports particulates but misses $\mathrm{CO}_{2}, \mathrm{SO}_{2}$ and $\mathrm{N}_{2} \mathrm{O}$ emissions.

Table 5. Comparison of emission sources' contribution in total emissions

\begin{tabular}{lrrrrrr}
\hline Emission Source & \multicolumn{2}{c}{ NO $_{\mathbf{x}}$} & \multicolumn{2}{c}{ CO } & \multicolumn{2}{c}{ VOC } \\
\cline { 2 - 7 } Category & \multicolumn{1}{c}{ LAT } & \multicolumn{1}{c}{ PW } & \multicolumn{1}{c}{ LAT } & \multicolumn{1}{c}{ PW } & \multicolumn{1}{c}{ LAT } & \multicolumn{1}{c}{$P W$} \\
\hline Road Transport & $40.7 \%$ & $35.2 \%$ & $81.2 \%$ & $78.8 \%$ & $3.5 \%$ & $29.2 \%$ \\
Off road vehicles and machinery & - & $34.4 \%$ & - & $16.4 \%$ & - & $11.2 \%$ \\
Air \& Sea transport & $8.9 \%$ & $2.0 \%$ & $2.7 \%$ & $1.1 \%$ & $0.2 \%$ & $0.7 \%$ \\
Power plants & $42.7 \%$ & $19.6 \%$ & $2.4 \%$ & $1.4 \%$ & $0.0 \%$ & $1.1 \%$ \\
Cement Industries & $3.3 \%$ & $4.3 \%$ & $6.1 \%$ & $0.6 \%$ & $0.2 \%$ & $0.2 \%$ \\
Small Industries & $4.1 \%$ & $1.6 \%$ & $1.4 \%$ & $1.2 \%$ & $0.1 \%$ & $0.4 \%$ \\
Mining and Quarrying & $0.0 \%$ & - & $0.0 \%$ & - & $0.2 \%$ & - \\
Storage and distribution of liquid & $0.0 \%$ & $0.0 \%$ & $0.0 \%$ & $0.0 \%$ & $0.7 \%$ & $2.7 \%$ \\
fuels & & & & & & \\
Solvent use & $0.0 \%$ & $0.0 \%$ & $0.0 \%$ & $0.0 \%$ & $2.1 \%$ & $7.3 \%$ \\
Waste management & $0.0 \%$ & - & $0.0 \%$ & - & $78.6 \%$ & - \\
Agriculture - Livestock & $0.0 \%$ & $1.9 \%$ & $0.0 \%$ & $0.0 \%$ & $14.3 \%$ & $39.6 \%$ \\
Forest fires & $0.3 \%$ & - & $6.2 \%$ & - & $0.3 \%$ & - \\
Production processes & - & $0.0 \%$ & - & $0.0 \%$ & - & $7.5 \%$ \\
Refinery & - & $0.8 \%$ & - & $0.5 \%$ & - & $0.1 \%$ \\
\hline
\end{tabular}

The issues that arise comparing these works are:

1. Emission sources categorization: each emission inventory classifies differently the emission sources it examines and possibly overlapping errors occur. In DLI inventories, no data is given about the methodology implemented, let alone the definition of emission source categories. In the present work the standard procedure of the internationally approved EMEP/CORINAIR methodology system is followed to overcome inconsistencies, examine effectively as many air pollution sources as possible and avoid double counting of emissions or other relevant problems.

2. Activity data: there is not a thorough description (if any at all) of the activity data and especially the activity data sources and manipulation in the other inventories. Therefore, from this point of view the comparisons concerning the emissions data estimates are somewhat problematic.

3. Emission factors: an important source of uncertainty in the emission estimates is attributed to the emission factor data set applied. It is certain that part of the deviation in the emission results originates from the use of different emission factors data sets: in the present work, country-specific emission factors are used (e.g. cement factory) and EMEP/CORINAIR default emission factors are adopted in the rest cases. In the work of Baumbach et al. EPA emission factors (for boilers for example) are applied. However, their appropriateness in Cypriot installations is questionable.

4. Methodology: in Baumbach et al. work, for example, the aircraft emissions estimation is a fuel-based procedure, while in the work presented a more detailed analysis (airplanespecific approach) is considered.

5. Weaknesses: the main weakness of the present work is that estimates of the Turkish Cypriot Community domain are not considered (due to the fact of no access to the necessary data).

6. Spatial allocation: although gridded maps are presented in Baumbach et al., yet no methodological guidelines are indicated to provide a meaningful spatial disaggregation of emissions. The spatial allocation of emission in the present work was described in detail 
in the methodology paragraph and examples are given in Figure 2. More specifically, in Figures 2(a), 2(b) and 2(c) the spatial allocation of NMVOC emissions from space heating, industry and highway traffic are presented respectively, highlighting the areas with higher emission densities (mainly urban areas and large industries locations). In Figure 3 gridded total NMVOC emissions are shown and emphasis is placed on peak emission values.

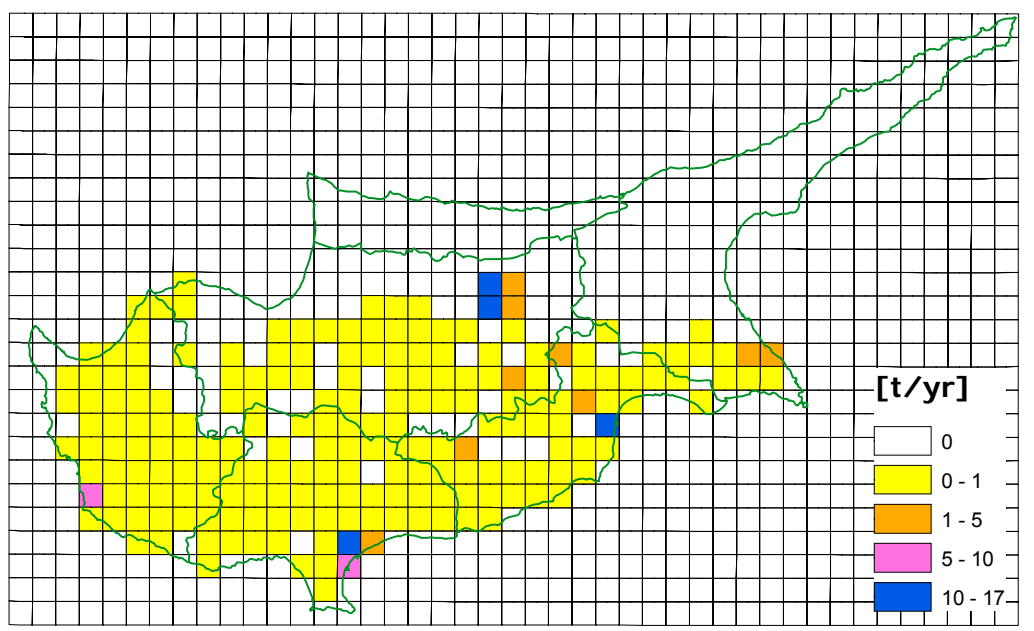

(a) Space heating

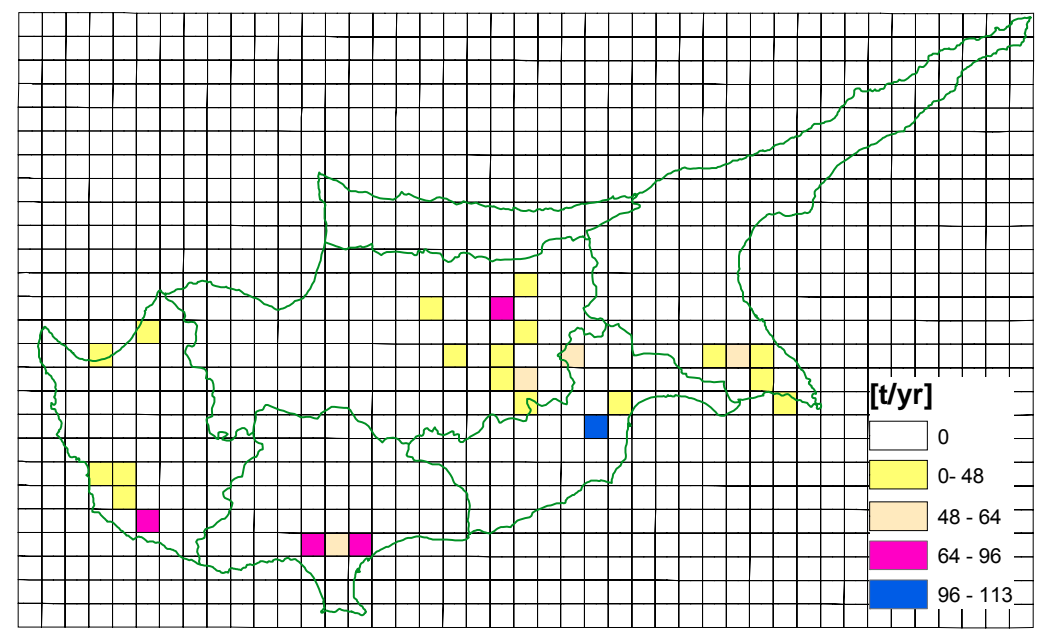

(b) Industry

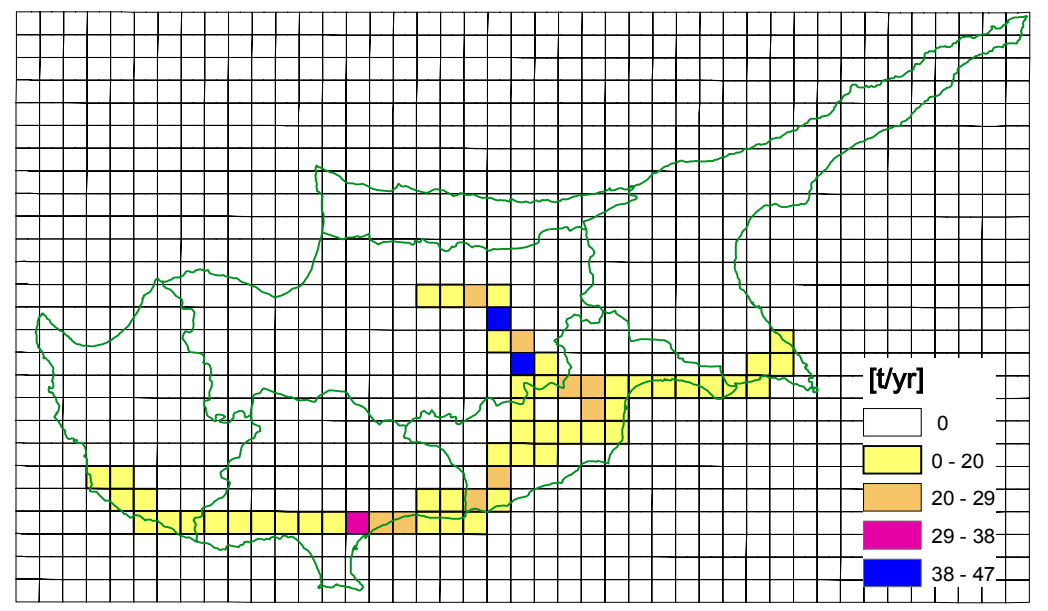

(c) Highway traffic

Figure 2. Spatial allocation of major sectors' NMVOC emissions in a $5 \times 5 \mathrm{~km}^{2}$ grid 


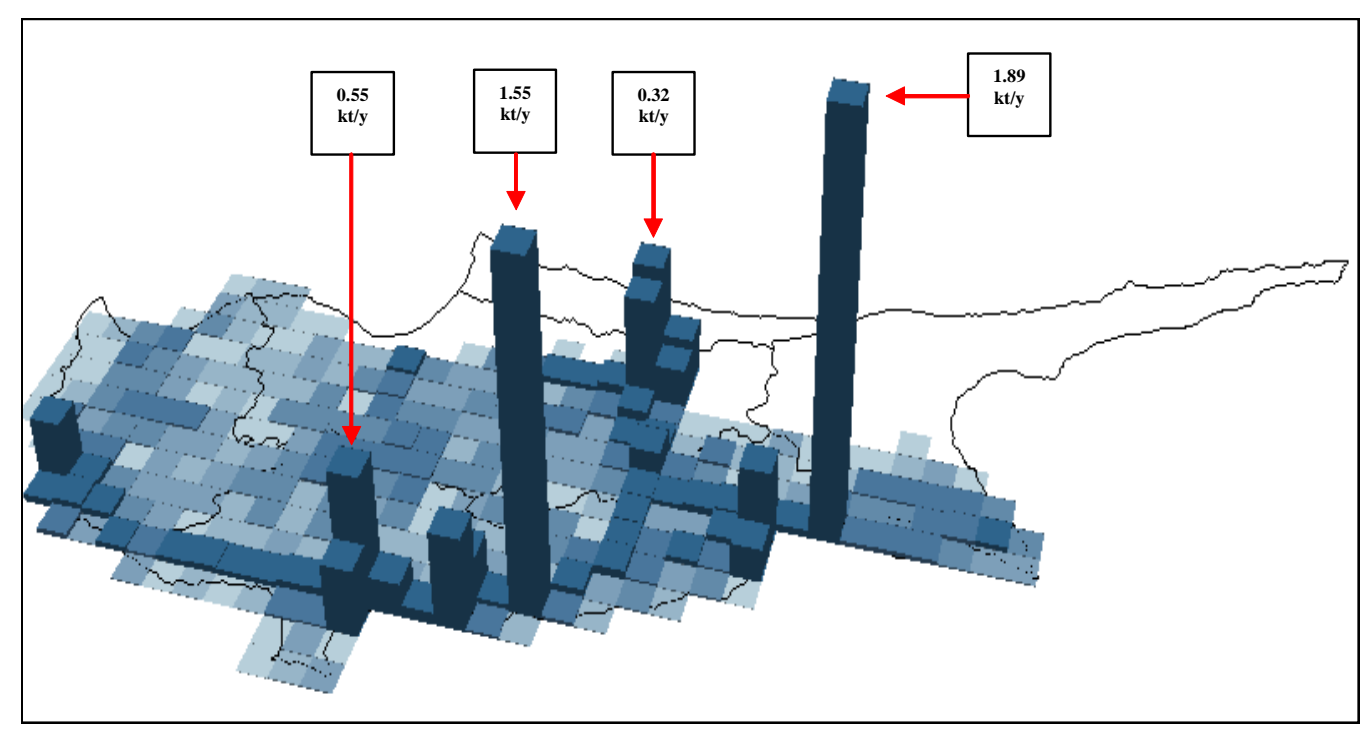

Figure 3. Spatial allocation and peak values of total NMVOC emissions

\section{CONCLUSIONS}

According to the emissions inventory, which covers the Greek-Cypriot community area presented in this paper, power generation and road transport are the main contributors to total emissions in Cyprus. Power generation share was $36 \%$ in total $\mathrm{CO}_{2}, 62 \%$ in total $\mathrm{SO}_{2}, 20 \%$ in total $\mathrm{NO}_{x}$ and $55 \%$ in total $\mathrm{N}_{2} \mathrm{O}$ emissions, while the share of road transport was $29 \%$ in total $\mathrm{CO}_{2}, 22 \%$ in total $\mathrm{SO}_{2}, 35 \%$ in total $\mathrm{NO}_{x}, 48 \%$ in total NMVOC and $78 \%$ in total $\mathrm{CO}$ emissions. The emission results are based on the acquisition and processing of a large amount of activity data and have been calculated with the aid of state-of-the-art algorithms. Cypriot-specific emission factors were used (where available) in the framework of an internationally approved emissions estimation method (EMEP/CORINAIR methodology).

Despite some weaknesses (e.g. coverage of emissions of Greek-Cypriot part only), this work contributes to the efforts for a more systematic approach of emission inventorying procedures in Cyprus, which are rather at a premature stage. The application, on which the emission inventory was based, is 'open', i.e. the activity and emission factor data can be easily revised/updated so that yearly emission inventories can be compiled. At the same time, emissions can be spatially allocated through an easy to use and functional tool. More specifically, the spatial allocation can be made possible with a GIS-aided approach and the generation of reliable data with high spatial resolution data can feed air quality models. The findings of this work can be used for preparing improved national emission estimates, producing maps of emission densities and as a basic source of information for air quality modelling.

Comparisons to other existing emission inventories for Cyprus and official national emission data show differences in the air pollutants set that each inventory reports and deviations in sector contributions to total emissions. Moreover, there are significant deviations in $\mathrm{NO}_{\mathrm{x}}$, NMVOC and $\mathrm{CO}$ emissions, but non-significant deviations for $\mathrm{SO}_{2}$ emissions, a fueldependent pollutant. To overcome these discrepancies, Cypriot authorities have to compare and evaluate all available emission inventories and totally or partially adopt methodologies used, calculation procedures, data sets, etc, so as to provide the most reliable emission results. Moreover, in future works the influence of natural emissions (e.g. resuspended dust, sea salt, VOCs) and their contribution in relation to the anthropogenic emissions has to be examined.

\section{ACKNOWLEDGEMENTS}

The authors wish to acknowledge financial support from the General Secretariat for Research and Technology (Greece) and the Research Promotion Foundation (Cyprus) made available for the bilateral programme 'Mapping of air pollutant emissions in Cyprus'. 


\section{REFERENCES}

Baldasano J.M. (1998), Guidelines and formulation of an upgrade source emission model for atmospheric pollutants, Air Pollution Emissions Inventory, H. Power and J.M. Baldasano (Eds.), Computational Mechanics Publications, Southampton, UK and Boston, USA.

Baumbach G., Bari A., Pfeiffer H., Sarachaga-Ruiz L., Kleanthous S., Poulida O. and Beyaz E. (2007), Assessment of air quality in Cyprus, Newsletter of WHO Collaborating Centre for Air Quality Management and Air Pollution Control, 39, 2-9.

Dai J. and Rocke D. (2000), A GIS-based approach to spatial allocation of area source solvent emissions, Environ Model \& Softwr, 15, 293-302.

Department of Labour Inspection (DLI), Annual reports on air quality in Cyprus, Internet site: http://www.airquality.dli.mlsi.gov.cy (accessed 02/2009).

EMEP/CORINAIR Atmospheric Emission Inventory Guidebook (2007), $3^{\text {rd }}$ edition, European Environment Agency, Copenhagen, Internet site: http://reports.eea.europa.eu/EMEPCORINAIR4/en (accessed 02/2009).

Mellios G. and Samaras Z. (2009), Emissions Inventory, Presentation in the Workshop Development of an emissions inventory and simulation of air quality in Cyprus, Nicosia, 30 January, 2009.

Sidiropoulos C. and Tsilingiridis G. (2006), Development of a spatial database for handling atmospheric emissions data in Greece: the case of road transport, E-Proc. of Int. Conf. Protection and Restoration of the Environment VIII, P-291, Chania, Greece, July 3-7, 2006.

Taghavi M., Cautenet S. and Arteta J. (2005), Impact of a highly detailed emission inventory on modeling accuracy, Atmos Res, 74, 65-88.

Tsilingiridis G. and Fessas J. (2008), Final Report of Greece - Cyprus Bilateral Project: Mapping of air pollutant emissions in Cyprus. (in Greek) 